Int. J. Morphol.,

35(2):459-464, 2017.

\title{
Configuration of Canal System in the Mesiobuccal Root of Maxillary First Molars
}

\author{
Configuración del Sistema de Canales en la Raíz \\ Mesiovestibular de los Primeros Molares Superiores
}

Marianne Spalding; Karla Mayra Rezende; Maria Claudia Garcia Silveira; Márcia Carneiro Valera \& Horácio Faig Leite

SPALDING, M.; REZENDE, K. M.; SILVEIRA, M. C. G.; VALERA M. C. \& LEITE, H. F. Configuration of canal system in the mesiobuccal root of maxillary first molars. Int. J. Morphol., 35(2):459-464, 2017.

SUMMARY: Knowledge on internal dental morphology is extremely important to the correct execution of the treatment and modeling of root canals. The aim of the present study was to analyze, "in vitro", the configuration of the canal system in the mesial root of 180 maxillary first molars obtained from a Brazilian sample. The teeth diaphanized in order to confirm the presence of the MB2 canal and to determine the internal anatomy. Only in $41 \%$ of the teeth the orifice of MB2 canal emerged from the pulp chamber floor. Among teeth two apical foramina were found in $23.3 \%$, a single apical foramen was observed in 15,5\% and three apical foramina were present in $2,2 \%$. Considering the hole sample, the MB2 canal was observed in $65.4 \%$, merged with the MB1 or branching from the MB1 or even independent all the way. In $55.1 \%$ of the teeth a single orifice stemmed from the pulp chamber floor. A single apical foramen was found in $43,5 \%$ of these cases, two apical foramina were present in approximately $12 \%$ and apical delta was found in $0,5 \%$ of the specimens. Three orifices which emerged from the pulpal floor were observed in $1.1 \%$ of the sample. Paths considered very atypical were observed at $2.8 \%$ of the teeth. The MB root canal anatomy was complex. The frequency of occurrence of the bifurcated or double canal, isthmus, accessory canals and apical delta must be taken into consideration as a possible cause of otherwise unexplained failure during endodontic treatment of first maxillary molars.

KEY WORDS: Molar; Root canal; Anatomy; Endodontics.

\section{INTRODUCTION}

The anatomy of root canal system has been the subject of many discussions and studies, as there are innumerous variations that need to be recognized so that clinicians can properly interpret the condition of the tooth and develop adequate treatment (Stropko, 1999; Kottoor et al., 2010; Verma \& Love, 2011; Grande et al., 2012; Spagnuolo et al., 2012). The evolution of endodontic techniques, associated to a growing knowledge on anatomic, morphological and biological aspects of root canal systems, enables a greater success rate in root canal treatment. A number of methods are used to assess the anatomic configuration of the pulp cavity, such as radiographic studies (Kulild \& Peters, 1990); tooth cutting (Weine et al., 2012), which contributes but does not allow a three-dimensional view of this cavity; tooth cutting in series (Kulild \& Peters), used in microscopic studies; metallic preparation, which do not allow the assessment of all the ramifications of the root canal; and diaphonization, which turns the tooth transparent, preserves its original anatomic form and allows a three-dimensional view of the tooth (Gilles \& Reader, 1990, Rehman et al., 2015). Recent studies have also described dental anatomy through spatial reconstruction with the assistance of computer programs (Baumann, 1994) using cone bean computerized tomography (Kottoor et al.), micro-CT (Verma \& Love; Yamada et al., 2011; Grande et al.; Spagnuolo et al.). However, some of these techniques are not suitable for clinical use, although it can become a powerful tool for research (Grande et al.).

\footnotetext{
${ }^{1}$ Departament of Bioscience and Oral Diagnosis, .Univ Estadual Paulista "Júlio de Mesquita Filho" -Dentistry School - Campus of São José dos Campos, SP, Brazil.

${ }^{2}$ Department of Pediatric Dentistry, Dental School, University of São Paulo-USP, São Paulo, SP, Brazil.

${ }^{3}$ Univ Estadual Paulista "Júlio de Mesquita Filho" -Dentistry School - Campus of São José dos Campos, SP, Brazil.

${ }^{4}$ Departament of Restorative Dentistry, Univ Estadual Paulista "Júlio de Mesquita Filho" -Dentistry School - Campus of São José dos Campos, SP, Brazil. ${ }^{5}$ Departament of Bioscience and Oral Diagnosis, Univ Estadual Paulista “Júlio de Mesquita Filho" -Dentistry School - Campus of São José dos Campos, SP, Brazil
} 
The detection rate of the mesiobuccal root of maxillary first molars has the greatest anatomic variation, leading to a high rate of unsuccessful endodontic treatment in these teeth (Stropko; Yoshioka et al., 2005; Grande et $a l$.). The greater complexity is due to the high percentage of the presence of a $4^{\text {th }}$ canal or MB2 canal (Gilles \& Reader; Kulild \& Peters) as well as considerable clinical limitations in its localization. It has been detected that the incidence of MB2 in vitro analysis is much higher as compared vivo, suggesting then it has a modification in the opening of access to the pulp chamber as contour alterations (Christie \& Thompson, 1994) to facilitate the location of this inlet channel (Weller \& Hartwell, 1989; Ting \& Nga, 1992; Stropko). The incidence of MB2 canal in vitro was much higher than its incidence in vivo. Weller \& Hartwell determined that and suggest a modification in the access opening to the pulp chamber in order to provide greater visualization and facilitate the localization of the entrance orifice in this canal. Contour alterations were also proposed by Christie \& Thompson, Ting $\& \mathrm{Nga}$ and Stropko. It was determined that the careful use of spherical endodontic broaches 2 to $3 \mathrm{~mm}$ below the pulp floor in the MBR increased the localization of the MB2 canal from $54 \%$ to $85 \%$ (Kulild \& Peters). Despite not having demonstrated an increased risk of perforations with the careful use of these broaches, it should be taken into account that this study was carried out in vitro, which facilitates the handling, visualization and execution of the procedures for these teeth (Kulild \& Peters).

Besides the high incidence and difficulties in locating the MB2 canal, there is considerable variation in the configuration of the canal system in the mesiobuccal root of

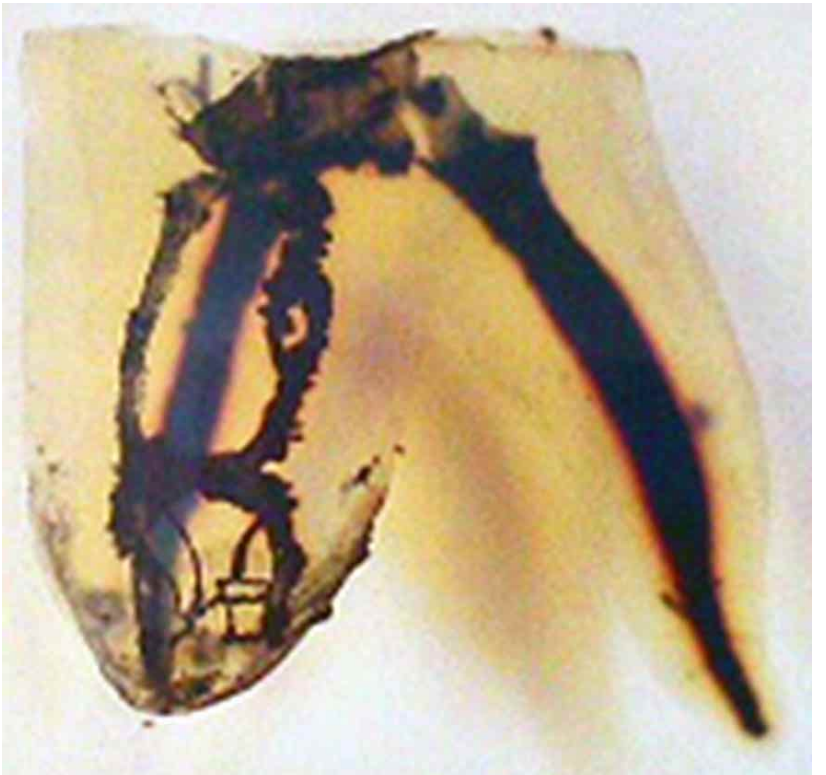

Fig. 1. Aspects of the root canals from the first molar after diaphanization. maxillary first molars (Verma \& Love; Yamada et al.; Gilles \& Reader; Grande et al.; Kulild \& Peters; Spagnuolo et al.; Weine et al.). The recognition of anatomic variations in root canals is the first and most important step toward successful treatment, as such variations emerge in teeth that have a normal outward appearance and clinicians must be aware of the importance of treatment of the canal system and not just the principal canals (Kim et al., 2012).

The aim of the present study was to assess the incidence of the second mesiobuccal-canal (MB2 canal) in the mesial root of the maxillary first molars, variations in the configuration of the canal system in this root and analyze the localization of the entrance to the canals in the pulp floor, correlating the internal tooth morphology with clinical aspects and difficulties encountered during the endodontic treatment of these teeth.

\section{MATERIAL AND METHOD}

One hundred eighty maxillary first molars were selected from the human tooth bank at the Anatomy Sector of the São José dos Campos Dental School of the Universidade Estadual Paulista "Júlio de Mesquita Filho" (UNESP). This study was approved by the Ethics Committee of Research (\# 1.115.757), Plataforma Brasil.

The crowns of the teeth were cut $2 \mathrm{~mm}$ beyond the enamel-cementum junction, placed in a 10 vol. hydrogen peroxide solution for 12 hours and then rinsed in running water. The pulp remaining in the chamber and root canals was removed with a curette and $n^{\circ} 0.8 \mathrm{~K}^{*}$ files. Scrapings were performed on the lateral, mesial and vestibular walls of the pulp chamber in order to allow greater visualization of entrance of the orifices in the canals of the mesiobuccal root, removing any dentin projections, but without touching or altering the pulp floor. With an exploratory probe and $\mathrm{n}^{\circ} 0.8 \mathrm{~K}^{*}$ files, the presence or absence of the entrance orifice to the MB2 canal was determined. To assess the internal configuration of the root canals, the teeth were submitted to diaphonization (Rehman et al.). The mesial and apical portions of the dental roots were then adjusted to a rubber sleeve attached to a suction device. With the help of a disposable syringe, ink was injected into the pulp chamber so that the dye infiltrated the root canals, allowing visualization of the internal morphology of the canals. It was thus possible to determine the presence of the MB2 canal, comparing its incidence with that determined by the previous probing with $n^{\circ} 0.8 \mathrm{~K}^{*}$ files; study the relationship between the MB and MB2 canal; observe the configuration of the canal system of the MBR in maxillary first molars; and analyze the presence of apical deltas (Fig. 1). 


\section{RESULTS AND DISCUSSION}

Considerable variety was observed in the morphology of the canal system in the mesiobuccal root of maxillary first molars (Fig. 1). From 180 teeth analyzed the presence of a single channel along the entire length of the MB root was observed in only $33.5 \%$. The MB2 canal was observed in $65.4 \%$ of the sample. It was a completely independent canal among 34 teeth, almost $19 \%$ of the sample. Only in $41 \%$ of the teeth the orifice of MB2 canal emerged from the pulp chamber floor. Two apical foramina were found in 23.3 $\%$, a single apical foramen was observed in $15.5 \%$ and three apical foramina were present in $2.2 \%$ of these teeth.

A single orifice stemmed from the pulp chamber floor in $55.1 \%$ of the teeth. In these cases, a single apical foramen was found in $43.5 \%$, two apical foramina were present in approximately $12 \%$.

Table I displays the anatomic variations observed in the canal system of the MB root for each of the different types of canals that went under a classification according to the configuration along the entire path.

The presence of three canals, from the cervical, was observed in two roots $(1.1 \%)$. Paths considered very atypical were observed at $2.8 \%$ of the teeth. Table II displays the canals that do not fit the previous classification and are therefore considered very atypical.

In the present study, the visual analysis of the pulp chamber and probing with an endodontic file allowed the identification of the MB2 canal in $41 \%$ of the teeth. After diaphanization, identification increased to $65.4 \%$, corroborating results obtained by Baldassari-Cruz et al. (2002), who found a rise in the percentage of MB2 canal using an additional method for the determination of the canal. According to the authors, in the visual examination with an exploratory probe, the MB2 canalwas detected in $51 \%$ of the molars analyzed, whereas with the assistance of an operating microscope, this canal was detected in $63 \%$ of the cases and after dissecting the roots, the MB2 canal was found in $89 \%$ of the cases. Kulild et al. also found that an endodontic probe detected the MB2 canal in only $54.2 \%$ of molars. The results obtained by the authors cited as well as in the present study partially explain the clinical difficulties encountered in the localization of this canal.

Furthermore, the presence of a second MB2 canal may originate from the main canal and not necessary have its own orifice in the pulp floor. This explains an increase from $54.2 \%$ to $85.5 \%$ in the detection of the MB2 canal after enlarging and deepening the mouth of the mesiobuccal canal with broaches or after dissecting the mesial root at different levels (Kulild \& Peters; Ting \& Nga, 1992). In a sample of 83 maxillary molars (including first and second molars). The same authors (Kulild \& Peters) found that just four teeth did not have the MB2 canal in the middle third of the mesial root.

The entrance orifice of the MB2 canal is often occluded by mineral deposits, thereby impeding its localization with dental instruments. In other cases, the canal goes undetected because it emerges as a single canal in the pulp floor and then bifurcates (Ting \& Nga). Current studies have demonstrated that the use of a operating microscope helps in the visualization and localization of the MB2 canal (Stropko; Görduysus et al., 2001; BaldassariCruz, et al.). However, the conclusion that a simple modification in the access and shape of the pulp chamber is enough to increase the percentage of localization. Alterations in contour shape have also been proposed by other authors, who found that the percentage of detection of the MB2 canal in vitro was much higher than in vivo (Christie \& Thompson; Sempira \& Hartwell, 2000; Weine et al.).

Previous studies have determined that the presence of the MB2 canal ranges from $25 \%$ to $96.1 \%$ (Neaverth et al., 1987; Weller \& Hartwell; Gilles \& Reader; Kulild \& Peters; Ting \& Nga; Stropko; Sempira \& Hartwell; Görduysus et al.; Alavi et al., 2002; Buhrley et al., 2002; Wolcott et al., 2002; Wolcott et al., 2005; Weine et al.). This discrepancy is likely due to the methodologies employed in each study as well as the sample size and regional location of the sample.

Table I Anatomic variations observed in canal system of the MB root.

\footnotetext{
01 tooth 2 canals that unite bifurc ate unite again, terminating in 1 foramen.

01 tooth 2 canals that unite in the mesial $1 / 3$ and terminate in 3 foramina - with inter-conduits

01 tooth 2 canals - MBL canal terminates in a blind bottom, therefore just 1 foramen.

01 tooth 1 canal bifurcates in the cervical $1 / 3$ cervical, forming 2 canals. The MB divides, terminating in 3 foramina.

01 tooth 1 canal that bifurcates into 3 in the cervical $1 / 3$, unites in the mesial $1 / 3$ and terminates in a delta.
} 


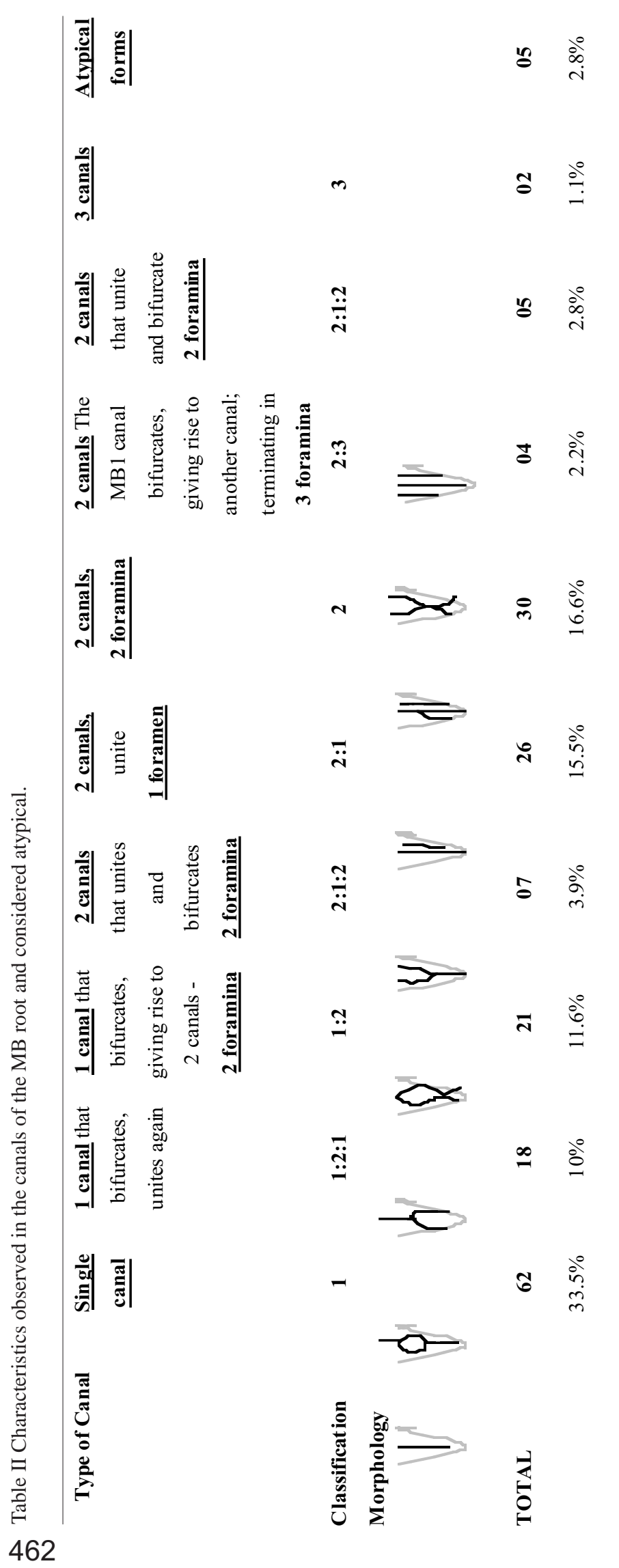

In a study with 228 maxillary first molars, Neaverth et al. found the $19.3 \%$ had one canal, 77.2 $\%$ had two canals and $3.1 \%$ had three canals, of which $35.6 \%$ terminated in one foramen, $61.8 \%$ terminated in two foramina and $0.4 \%$ terminated in three foramina. The authors correlated the number of canals and foramina and found that $18 \%$ had one canal and one foramen, $16.7 \%$ had two canals and one foramen and $60.1 \%$ had two canals and two foramina. In a recent study, Spagnuolo et al., used micro-CT to analyze mesiobuccal roots or 22 first molars and observed that MB2 canal was presented in $77.27 \%$, and $29.41 \%$ of the MB2 canals were independent from the MB1 canals. Stropko et al. noted that that MB2 canal was found in 802 (73\%) first molars, however, as the operator become more experienced, scheduled sufficient clinical time, routinely employed the dental operating microscope and used specific instruments adapted for microendodontics, MB2 canal were located in $93 \%$ of first molars.

The morphology of the canal systems in the mesial root of the maxillary first molar proved extremely complex in the present study, with canals that began as singles canals, but bifurcated at different levels, forming two canals. Some specimens exhibited a single canals that bifurcated, came back together and separated again. Some have two canals ran their entire length independent from one another, while at other specimens, two canals united, terminating in a single canal. As it was demonstrated on Tables I and II, other configurations were present as well. With the current use of more accurate techniques for the detection of the MB2 canal, the classification of the canal system initially proposed by Weine et al. as single, double ending in one foramen or double ending in two foramina becomes extremely simplistic. Some researches still based on the types of root canal configurations from the classification by Weine et al., this search classification of the root canal configuration in eight types (I - VIII) based on the presence of one, two or three canals in the pulp floor as well as the presence of one or more canals emerging in the root apex (Vertucci, 1984). However, more than eight types were observed in the present study. We sought to classify the types by obeying a numerical criterion in order to establish the number of canals in the floor, bifurcations or unions throughout their courses as well as the number of canals emerging in the apex, as displayed in Table I.

With the use of a stereomicroscope, it was observed that the MB root has a rather complex 
anatomy, with the presence of lateral canals, recurrent interconduits and an apical delta. Variation also occurs in the shape of the entrance to the mesiobuccal root canals, which can have two independent entrance orifices for the MB1 and MB2 canals or a single entrance orifice in a circular or elliptical shape, with a narrowing in the central portion. The MB2 canal is located mesially to the anatomic furrow of the pulp floor. Between the MB and lingual canals the presence of a dentin shoulder in the entrance of the MB2 canal is common, hindering its direct visualization (Ting \& Nga).

Clinically, it is recommended to perform a compensatory scraping on the entrance of this canal, enlarging and deepening it so as to allow its localization. This scraping should be performed with the maximum care in order to avoid a perforation in the pulp floor (Ting \& $\mathrm{Nga}$ ). Due to the anatomic complexities and clinical difficulties encountered in the localization of the MBL ca- nal, it is important to establish a correct access. We believe that the access opening to the canals is a fundamental step toward localizing the MB2 canal as the bifurcation of the MB1 canal often occurs in the cervical third (Neaverth et al.; Kulild \& Peters; Sempira \& Hartwell). Moreover, endodontic treatment should consider the possible anatomic variations of the canal system in the MB root and perform a correct biomechanical preparation, with germicide irrigating solutions and intra-canal medication in order to improve the prognosis of root canal treatment carried out in the maxillary molars.

The variation in the anatomic configuration of the canal system in the mesial root of maxillary first molars warns us that during endodontic therapy, there is the need for a more discerning access opening to the canals as well as the proper instrumentation associated to adequate medication therapy in order to reach the entire network of canals and conduits in this root in the best possible manner.

SPALDING, M.; REZENDE, K. M.; SILVEIRA, M. C. G.; VALERA M. C. \& LEITE, H. F. Configuración del sistema de canales en la raíz mesiobucal de los primeros molares superiores. Int. J. Morphol., 35(2):459-464, 2017.

RESUMEN: El conocimiento de la morfología dental interna es muy importante para la correcta ejecución del tratamiento de conductos radiculares. El objetivo del presente estudio fue analizar "in vitro", la configuración del sistema de canales en la raíz mesiobucal del 180 primeros molares maxilares obtenidos de una muestra brasileña. Mediante el uso de la diafanización de los dientes se confirmó la presencia del canal MB2 y su anatomía interna. Solamente $41 \%$ de los dientes el canales MB2 emergió desde el piso de la cámara pulpar. De estos dientes fueron encontrados dos forámenes apicales en 23,3\%, un solo foramen apical en $15,5 \%$ y tres forámenes apicales estaban presentes en el 2,2\%. Teniendo en cuenta la totalidad de la muestra, 65,4 \% presentaron el MB2; que se fusionó con el MB1, a veces se observó como una rama de este canal, o sigue siendo independiente hasta el final. En 55,1\% de los dientes un solo foramen provenía del piso de la cámara pulpar. Un solo foramen apical se encontró en 43,5\% de estos casos, dos forámenes apicales estaban presentes en aproximadamente el $12 \%$ y el delta apical se encontró en 0,5\% de los especímenes. Tres canal a partir del piso pulpar se observaron en $1,1 \%$ de la muestra. Caminos considerados muy atípicos se observaron a $2,8 \%$ de los dientes. La morfología del sistema de canales radiculares en la raíz MB de los primeros molares maxilares es compleja y variable. La alta frecuencia de canal MB2, bien como la presencia del canal bifurcado o doble, istmo, conductos accesorios y delta apical deben tenerse en cuenta como posible causa de la falla de otro modo inexplicable durante el tratamiento endodóntico de los primeros molares maxilares.

PALABRAS CLAVE: Molar; Canal raíz; Anatomía; Endodoncia.

\section{REFERENCES}

Alavi, A. M.; Opasanon, A.; Ng, Y. L. \& Gulabivala, K. Root and canal morphology of Thai maxillary molars. Int. Endod. J., 35(5):478-85, 2002.

Baldassari-Cruz, L. A.; Lilly, J. P. \& Rivera, E. M. The influence of dental operating microscope in locating the mesiolingual canal orifice. Oral Surg. Oral Med. Oral Pathol. Oral Radiol. Endod., 93(2):190-4, 2002.

Baumann, M. A. A new approach to demonstration of root canal anatomy. J. Dent. Educ., 58(9):704-8, 1994.

Buhrley, L. J.; Barrows, M. J.; BeGole, E. A. \& Wenckus, C. S. Effect of magnification on locating the MB2 canal in maxillary molars. J. Endod., 28(4):324-7, 2002.

Christie, W. H. \& Thompson, G. K. The importance of endodontic access in locating maxillary and mandibular molar canals. J. Can. Dent. Assoc.,
60(6):527-32, 1994

Gilles, J. \& Reader, A. An SEM investigation of the mesiolingual canal in human maxillary first and second molars. Oral Surg. Oral Med. Oral Pathol., 70(5):638-43, 1990.

Görduysus, M. O.; Görduysus, M. \& Friedman, S. Operating microscope improves negotiation of second mesiobuccal canals in maxillary molars. J. Endod., 27(11):683-6, 2001.

Grande, N. M.; Plotino, G.; Gambarini, G.; Testarelli, L.; D'Ambrosio, F.; Pecci, R. \& Bedini, R. Present and future in the use of micro-CT scanner 3D analysis for the study of dental and root canal morphology. Ann. Ist Super. Sanita., 48(1):26-34, 2012.

Kim, Y.; Lee, S. J. \& Woo, J. Morphology of maxillary first and second molars analyzed by cone-beam computed tomography in a korean 
SPALDING, M.; REZENDE, K. M.; SILVEIRA, M. C. G.; VALERA M. C. \& LEITE, H. F. Configuration of canal system in the mesiobuccal root of maxillary first molars. Int. J. Morphol., 35(2):459-464, 2017.

population: variations in the number of roots and canals and the incidence of fusion. J. Endod., 38(8):1063-8, 2012.

Kottoor, J.; Velmurugan, N.; Sudha, R. \& Hemamalathi, S. Maxillary first molar with seven root canals diagnosed with cone-beam computed tomography scanning: A case report. J. Endod., 36(5):915-21, 2010.

Kulild, J. C. \& Peters, D. D. Incidence and configuration of canal systems in the mesiobuccal root of maxillary first and second molars. J. Endod., 16(7):311-7, 1990.

Neaverth, E. J.; Kotler, L. M. \& Kaltenbach. R. F. Clinical investigation (in vivo) of endodontically treated maxillary first molars. J. Endod., 13(10):506-12, 1987.

Rehman, K.; Khan, F. R. \& Habid, S. Diaphonization: a recipe to study teeth. J. Contemp. Dent. Pract., 16(3):248-51, 2015.

Sempira, H. N. \& Hartwell, G. R. Frequency of second mesiobuccal canals in maxillary molars as determined by use of an operating microscope: a clinical study. J. Endod., 26(11):673-4, 2000.

Spagnuolo, G.; Ametrano, G.; D'Antò, V.; Formisano, A.; Simeone, M.; Riccitiello, F.; Amato, M. \& Rengo, S. Microcomputed tomography analysis of mesiobuccal orifices and major apical foramen in first maxillary molars. Open Dent. J., 6:118-25, 2012.

Stropko, J. J. Canal morphology of maxillary molars: clinical observations of canal configurations. J. Endod., 25(6):446-50, 1999.

Ting, P. C.; \& Nga, L. Clinical detection of the minor mesiobuccal canal of maxillary first molars. Int. Endod. J., 25(6):304-6, 1992.

Verma, P. \& Love, R. M. A Micro CT study of the mesiobuccal root canal morphology of the maxillary first molar tooth. Int. Endod. J., 44(3):2107, 2011.

Vertucci, F. J. Root canal anatomy of the human permanent teeth. Oral Surg. Oral Med. Oral Pathol., 58(5):589-99, 1984.

Weine, F. S.; Healey, H. J.; Gerstein, H. \& Evanson, L. Canal configuration in the mesiobuccal root of the maxillary first molar and its endodontic significance. 1969. J. Endod., 38(10):1305-8, 2012.

Weller, R. N. \& Hartwell, G. R. The impact of improved access and searching techniques on detection of the mesiolingual canal in maxillary molars. J. Endod., 15(2):82-3, 1989.

Wolcott, J.; Ishley, D.; Kennedy, W.; Johnson, S. \& Minnich, S. Clinical investigation of second mesiobuccal canals in endodontically treated and retreated maxillary molars. J. Endod., 28(6):477-9, 2002.

Wolcott, J.; Ishley, D.; Kennedy, W.; Johnson, S.; Minnich, S. \& Meyers, J. A 5 yr clinical investigation of second mesiobuccal canals in endodontically treated and retreated maxillary molars. J. Endod., 31(4):262-4, 2005.

Yamada, M.; Ide, Y.; Matsunaga, S.; Kato, H. \& Nakagawa, K. Three-dimensional analysis of mesiobuccal root canal of Japanese maxillary first molar using Micro-CT. Bull. Tokyo Dent. Coll., 52(2):77-84, 2011.

Yoshioka, T.; Kikuchi, I.; Fukumoto, Y.; Kobayashi, C. \& Suda, H. Detection of the second mesiobuccal canal in mesiobuccal roots of maxillary molar teeth ex vivo. Int. Endod. J., 38(2):124-8, 2005.
Corresponding author:
Marianne SPALDING

Av Fco José Longo 777

São José dos Campos

CEP: 12.245 .000

São Paulo

BRAZIL

E-mail: marianne@fosjc.unesp.br

Received: 14-01-2016

Accepted: 13-02-2017 